\title{
Business Communication Research and Theory Development in Asia: Past, Present, and Future Prospects
}

\section{Bertha Du-Babcock}

City University of Hong Kong, Hong Kong

Objectives: Multinational corporations headquartered in Asia have steadily taken a greater market share in the global marketplace. This growth will continue, and Asia will be the leading economic force in the 21st century. This article attempts to provide a critical review of the literature of international business and business communication in Asia over the last two decades.

Methods: This paper describes and reviews intercultural communication and business research and theory development in Asian multinational corporations. It traces the development of cultural, linguistic, and international business streams of research and theory development. Existing models and frameworks that can guide research and theory building are presented to lead to a unified theory of Asian business communication.

Results: It was shown how distinct management and communication systems developed in Japan, Korea, overseas Chinese countries, and Mainland China. These streams were largely independent and are now going through an initial period of integration.

Conclusions: There are hopeful signs for expanded research and theory building on Asian business communication. Scholarship and research is shifting to Asia as a way of following the movement of global business communication. A comprehensive framework, theories, and models are needed in order to guide future research endeavors in this increasingly diverse and complex globalized business communication environment and to provide a more complete and comprehensive explanation of international and Asian business communication.

Key Words: Business Communication, Intercultural Communication, International Business, Language-based Communication, Asia

\section{Introduction}

Commencing in the 1980s, multinational corporations (MNCs) headquartered in Asia have steadily taken a greater market share

Received: Nov 1, 2017 Revised: Nov 28, 2017 Accepted: Dec 2, 2017

Corresponding author: Bertha Du-Babcock

Department of English, City University of Hong Kong, 83 Tat Chee Avenue, Kowloon Tong, Hong Kong

Tel: +852-3442-9600, E-mail: enbertha@cityu.edu.hk

This is an Open Access article distributed under the terms of the Creative Commons Attribution Non-Commercial License (http://creativecommons.org/licenses/by$\mathrm{nc} / 4.0 /$ ) which permits unrestricted non-commercial use, distribution, and reproduction in any medium, provided the original work is properly cited. Copyright $\odot 2018$ Korean Association for Business Communication. in the global marketplace. It has been projected that this growth will continue and that Asia will be the leading economic force in the 21st century. Japan was the initial global entrant followed by the Four Little Dragons or Tigers (i.e., Korea, Hong Kong, Taiwan, and Singapore) and then Mainland China. India and the ASEAN countries are presently in the early stages of expanding into global markets. This business and economic activity has stimulated research and theory building that have been directed at reporting and explaining the management and communication practices in these Asian MNCs. Building on a framework of Western developed theory, the universal aspects of the Western developed theory were adopted while adaptations were and 
are being made in order to account for culture, language, and the Asian business context. Historical factors affecting Asian management and communication have been underreported in Western literature in that articles and sections of articles have often served as a "catch up" to inform Western readers about relevant Asian factors.

Scholars from different academic disciplines have studied and analyzed Asian management and communication practices from the perspective of their respective fields, which has resulted in the development of a silo effect (Craig, 1999; Du-Babcock, 2014; Suchan \& Miljaliisa, 2006), with separate research and theory building streams. Some confusion and contradictions exist in the literature as communication practices and patterns in Asian MNCs have changed over the years since the 1980s. In being exposed to other cultures and business practices, traditional management and communication practices have sometimes changed unevenly as Asians have adapted them when moving into the global marketplace. Consequently, some research and theory development may have been built on outdated information describing management and communication practices at a historical period and therefore now needs to be updated in line with present practice.

This article attempts to provide a critical review of the literature of international (business) communication and international business research on Asia over the last two decades as "Intercultural communication became a noticeable sub-area of Asian communication studies only in the 1990s" (Kim, 2010, p. 166). Although my focus is on Asian business communication, I also include some theory and research on Western communication so as to provide a more comprehensive review of Asian business communication. In this article, I will review and describe the research and theory building in three identified streams of culture, language, and international business. Next, I will further suggest how the integration of these three streams can be implemented and suggest ways of moving towards the development of an integrated and more complete theory of Asian management and business communication in the future.

\section{Three Streams in Business Communication Research and Theory}

Culture, language, and international business are the three constructs chosen to be the focal point of this discussion because of their important role in shaping Asian business communication research and practice. Culture is an important concept and is most researched when understanding communication in Asian business contexts and often suggests that the Asian style of communication is challenging and complex. Language is chosen for two reasons. First, cultural theory did not acknowledge the influence of language competency in intercultural communication (Babcock \& Du-Babcock, 2001; Peltokorpia \& Clausen, 2011). Second, the world of business has become more globalized and intercultural encounters are likely to reside with individuals speaking different national languages and with varying degrees of English language competency. Language is a form of communication. Without adequate language competence, critical information may be "lost in translation" or cause misunderstandings based on cross-cultural communication nuances. The third construct is international business. The 21st century is the Asian century. As Asia has increasingly played an important role in the global business arena, there is an increasing contact with Asians. Knowledge of managing international business is the key to the success of these international business encounters. In this review of the literature section, I critically review these three constructs by highlighting the research being done in the field that is particularly relevant in Asian countries.

\section{Cultural Stream}

The cultural theories and research of Hofstede (2001) and Hall (1976) have collectively provided a framework of cultural differences among countries and communication styles to guide research and theory development. Hofstede's landmark study of cultural dimensions identified Western countries as individualist and Asian countries as collectivist. Focusing directly on communication, Hall differentiated high-context and low-context communication styles with high-context communication predominating in Asian countries and low-context communication predominating in Western countries. These research paradigms have provided the basis for understanding the messages from another culture but did not set forth prescriptions on how to encode and decode messages. In the next section. I review the research topics in relation to cultural influence.

\section{Cultural Influence on Turn Taking Behaviors}

Using Hofstede's individualist-collectivist (IC) continuum and Hall's distinction of low-context and high-context communication styles, many researchers have investigated aspects of communication in a variety of cultures (Gudykunst et al., 1996; Oetzel, 1998; Oetzel, Ting-Toomey, \& Rinderle, 2006), and conflict styles (Ting-Toomey, 2008). In recent years, there has been an increasing number of research studies adopting the IC theoretical construct to examine the impact of cultures on turn-taking behaviors by Asians. Studies on turn-taking by Aritz and Walker (2010), Fujio and Tanaka (2012), and Iwata (2010) have found that culture influences Asian's communication behavior. The results of their studies also confirmed the findings of Yamada (1990) 
and Gudykunst and Nishida (1994), suggesting that patterns of turn-taking distribution can be linked to cultural differences. These studies have validated the construct that collectivist cultures stress group harmony rather than individual gains, which is the main orientation in individualistic cultures.

In Hong Kong, Bilbow (1997) and Rogerson-Revell (1999) examined the meeting interactions of Western English-speaking expatriates and local Cantonese-speaking Chinese in large MNCs, concluding that culture could be a determining factor in the participation rate of Hong Kong Chinese bilinguals in top management meetings. Their findings revealed that Westerners were much more active than the Cantonese and attributed their findings to cultural differences. Du-Babcock and Tanaka's (2013) study updated cultural influence on communication behaviors of business professionals from Japan and Hong Kong when these professionals participated in intercultural and intracultural decision-making meetings. Their study reveals that culture affected the communication behaviors of the Japanese and the Hong Kong Chinese business professionals. Although both researched groups generally reflected their high-context communication orientations, they exhibited some deviations from these discourse patterns, especially when expressing disagreements. Their findings on culture's influence on communication strongly suggest that the high-and low-context communication dimensions should be thought of as existing on a continuum rather than as being distinct or situated in opposite categories. On the suggested continuum, both the Japanese and the Hong Kong Chinese exist on the collectivistic side of the continuum, but the Hong Kong Chinese tend to be located more toward the individualistic end of the continuum.

Bargiela-Chiappini and Tanaka's (2011) study reveals that the turn-taking frequency of the managers was higher than that of employees when the discussion focused on management issues. In comparison, the turn-taking frequency for employees and managers was equivalent when the discussion concerned employees' responsibilities. The researchers explained that the unequal distribution of turns may have arisen from participants' concern for relationship maintenance. Their findings are consistent with data from the Cambridge and Nottingham Business English Corpus meetings, suggesting that the power relationship between speakers, not cultures, can be a relevant factor in unequal turn-taking distribution (Handford, 2010).

\section{Cultural Influence on Expatriate's Overseas Adjustment}

Another set of research on culture examines the impact of culture focused on expatriate adjustment. This initial intercultural communication research focused on Americans and was stimulated by the excessively high levels of failure rates of expatriate managers stationed in Asia. Tung (1987) found that over 50\% of American expatriates failed to complete their Asian overseas assignments. Research investigating the reasons for this failure rate focused on the cultural adaption to the overseas environment, on-the-job adaption, off- the-job personal adaptation, and family adaptation. The overall findings suggested that the inability to make personal and family adaptations constituted larger obstacles to adaptation than on-the-job adaptation. The research also identified a six- month adjustment period in which to reach a steady equilibrium.

Other studies in the area of expatriate adjustment, for nearly three decades, has paid great attention to Western expatriates (Black, Gregersen, Mendendall, \& Stroh, 1999; Breiden, Mohr, \& Mirza, 2006; Caligiuri \& Lazarova, 2002; Du-Babcock, 2000; Herleman, Britt, \& Hashima, 2008; Takeuchi, Lepak, Marinova, \& Yun, 2007). Due to the shift of economic growth to Asia, this geographic region is increasingly sending large numbers of expatriates to foreign postings from its multinational corporations (MNCs). Hence, in the last decade researchers have started focusing on how expatriates from mainland China (Cao, 2008; Xu \& Du-Babcock, 2012), Taiwan (Chi \& Yeh, 2006), and Japan (Peltokorpi, 2007, 2010) adjust to their overseas assignments.

\section{Cultural Influence on Conflict Management}

Cultural influence on Asian communication has also examined how Asians resolve conflicts. There has been an extensive research group led by Rahim examining conflict management from various aspects. Yet, the results from earlier studies on the role of culture in managing conflicts have not been consistent and conclusive (Leung, 1988). Leung argued that although a number of theorists have suggested that Asian managers are more disposed to an avoidance style than Western managers, the Asian in-group/out-group differences may also have influenced the way of dealing with conflict avoidance between both in-group and out-group members. A study by Wei, Yuen, and Zhu (2001) examined how national culture, organizational culture, and managerial factors influence managers' conflict resolution styles. This empirical study consisted of 600 managers working in Singapore. The managers came from four subgroups and were equally divided into Americans, Japanese, Chinese, and Singaporeans working in MNCs and Singaporeans in local companies. The results revealed that American managers were more likely to resort to the dominating and integrating style than their Asian counterparts. Other studies examine the differences of handling conflict resolution by Asians (Hong, 2005; Lather, Jain, \& Vikas, 2009; Ma, 2007; Majumdar, 2015; Mohammed, Prabhakar, \& White, 2008; Ohbuchi et al., 1999; Suppiah, 2006). These studies show that the preferred conflict resolution style by 
Asians was both accommodating and avoiding.

Using Rahim's conflict management framework, Du-Babcock (2013) studied how Asian managers resolved conflicts differently at three organizational levels; namely, to their superiors, to their peers, and to their subordinates. The results show that collectivist and individualist managers handled conflicts differently when sorting out conflicts with superiors, subordinates, and peers. The findings reveal that in the business world, the major aim is to solve problems and get the tasks done, and therefore, an obliging style and avoiding style are the least favorable conflict management styles adopted by Hong Kong Chinese managers. Instead, an integrating style and compromising style were preferred by the interviewees regardless of cultures. The interviewees commented that the use of avoiding a conflict resolution style and its negative effects may affect teamwork and productivity when one party involved in the conflict is always ignore, or when the conflict goes unaddressed. Therefore, it is important to work out a decision that is acceptable to both sides when conflict occurs. Du-Babcock's findings deviate from earlier research concluding that Asians are more likely to use avoiding or obliging conflict resolution styles.

The possible underpinning of cultural influences on Asian management and communication has been attributed to key cultural values rooted in the historical development of Asian countries. I am presenting these concepts as a backdrop for interpreting the cultural influences on Asian business communication. The Asian countries all share a Confucian heritage culture (Phuong-Mai, Terlouw, \& Pilot, 2005). Confucian principles have had significant influence in organizing (traditional) Asian societies and offered a way of organizing individuals in Asian societies, particularly in Chinese society. The five cardinal virtues of Confucianism stipulated the determined or assigned roles in a fixed system of relationships. Influenced by Confucian principles, Chinese are taught to have situational orientation (Hsu, 1981). That is, each individual acts out their prescribed role, and the pressure to conform to these roles serves as an integrating mechanism in these societies. The long-established Confucian value system has significantly impacted how superiors and subordinates interact in business and organizational contexts. Confucian doctrine has provided a structure to guide relationships among people, and this may carry over to communication within organizations.

To ensure that a society functions well, two major essences of Chinese culture that foster a harmonious society are face behavior and guanxi (or relationship). Bond's (1991) classic book delineated the complexity of the concept of face behaviors. The idea of guanxi is to develop relationships by giving favors and creating indebtedness for repayment. Relationships are a vital force in Asian societies, and even more so in large and small Chinese enterprises. Although communication proceeds through a vertical command chain in routine situations, Chinese employees in positions of authority and power use their connections to "cut" through the bureaucratic bottlenecks and overturn arbitrary decisions. Hence, exhibiting appropriate face behaviors is crucial to cement this everlasting relationship. The concept of "face saving and giving" (in the Chinese sense) is complex and elusive, especially to outsiders. The concept of face exists in all cultures (Brown \& Levison, 1987; Goffman, 1967; Hsien, 1944; Ting-Toomey, 1985). Broadly speaking, face is an unwritten set of rules which people in society use to prevent damaging other's autonomy and gain self-respect. Face is manifested linguistically in various devices used for expressing politeness and pragmatic appropriateness. Because of this, Chinese employees tend not to disclose disagreements explicitly so as to save or give face to their counterparts. Being a collective society influenced by Confucian ethics, the behaviors of saving and enhancing face in Asian society are crucial in social interaction, and even more so to the Chinese. Du-Babcock and Tanaka's research findings (2013) provide evidence that the disclosure of opinions and disagreements are affected by cultural preferences. Both Chinese and Japanese business professionals coming from collective cultural societies are likely to exhibit high-context communication by sharing contextual information first and expressing their opinion towards the very end of their turn to speak. In so doing, they can minimize conflict and encourage interactional harmony.

\section{Language Stream}

\section{Theory Development of Language-Based Communication Zones Model}

The language stream originated later than the cultural stream and acknowledged a cultural influence on management and communication from its inception. The stream can be dated back to an empirical study of expatriate communication in 14 MNCs in Taiwan (Du-Babcock \& Babcock, 1996). The results of this study established that the expatriates communicated in three language-based communication zones based on Western expatriate's Mandarin competency. In Zone One, the expatriates with limited or no Mandarin competency communicated to the Chinese staff through intermediaries in link-pin channels. In Zone Two, the expatriates with partial Mandarin competency communicated directly with the Chinese staff for some message, but still relied heavily on link-pin channels. In Zone Three, the expatriates with full Mandarin competency could communication directly with Chinese staff in all situations and did not have to rely on language link-pins. The 1996 model concentrat- 
ed primarily on expatriates and did not analyze the Chinese perspective in this two-way communication process. Drawing on the same data set, but also adding additional data, a general and comprehensive model was sequentially developed (Babcock \& Du-Babcock, 2001; Du-Babcock \& Babcock, 2007). The model was further developed to represent a two-way communication flow and to more fully define language competency by distinguishing general language and genre language competencies. While general language is the ability to carry out a general conversation, genre language competency is the ability to communicate in a specific language area. Three genre categories were designated: professional genre, commercial or organizational genre, and relational genre (Refer to Babcock \& Du-Babcock, 2007 for details). Peltokorpia (2010) verified the importance of genre competency in his studies of language in Japanese MNCs. $\mathrm{He}$ found that genre language competency was the critical determinant of successful communication after communicators reached an advanced but not necessarily full general language competency level.

\section{Development of Business English as Lingua Franca}

English as a lingua franca in a business context (or BELF) has been the focus in Europe for the past two decades. Scholars such as Nickerson (2002), Bargiela-Chiappini (2006), and LouhialaSalminen, Charles and Kankaanranta (2005) have contributed a great deal to this line of research by examining the effect of English as business or corporate languages in international business contexts. Aside from research conducted in a European context, in Asia, other studies have also investigated the communication behaviors of non-native English business professionals in multinational business meetings (Bilbow, 2002; Du-Babcock,1999, 2005, 2006; Du-Babcock \& Tanaka, 2013; Du-Babcock, 2013; Rogerson-Revell, 1999). Kameda (2013) proposed the development of regional BELFs as a lingua franca in different regions of Asia. This proposal was founded on the notion that Asian people in different regions of Asia have different common features of communication and similar ways of using English. To operationalize the regional BELF based on the concept of Global English or Globish, Kameda (2013) noted that there needed to be some limitations in the use of BELF in order to guarantee mutual intelligibility. In doing so, he proposed adding 500 of the most often used business vocabulary words to the 1,500 that he had originally proposed constituting approximately 2,000 basic BELF words or Global business English (or Globish) words. According to Kameda, these regional BELFs could be divided into three groups: (A) BELF for use in primary industry (e.g., agricultural language); (B) BELF for secondary industry (e.g., manufacturing and construction language); and (C)
BELF for tertiary industry (e.g., value added servicing such as financial language). In doing so, he proposed that 300 of these 500 additional words should be used for each industry's own terminologies, while the remaining 200 words would be shared by the three industries but also used for management, trade, and marketing.

Perhaps a realistic starting point is to define and identify vocabulary that can be shared to form a universal BELF (core area of BELF), or what Du-Babcock (2012) called a common core. The second step is the identification of a local BELF (industry specific) that is practiced and used in each of the three sub-categories. While the universal BELF is used for intelligibility, the local BELF can be more genre specific and related to a designated industry. Aligned with Kameda's categories, Du-Babcock (2012) proposed a two-tier system. The first tier of BELF or Global English contains a pool of universal BELF vocabulary used by all industry or the common core of universal BELF. The second-tier is the local BELF, for which each industry could develop its own genre-specific words fitting its own industry.

\section{Research on First Language (L1) and Second Language (L2) Communication}

Research on L1 and L2 communication of these bilinguals has helped to advance a deeper theoretical understanding. These studies have provided some, but not a complete understanding of the mutual and interactive influence of language competency and culture. Research examining the impact of language on communication behaviors has focused on English intercultural communication in which Asians were speaking in their second language (Bilbow, 1997; Rogerson-Revell, 1999). In these studies, researchers have found that native and non-native English speakers exhibited different communication behaviors in intercultural meetings. Yamada's (1990) study revealed that the Japanese business professionals were also less active than their Western counterparts.

To examine the impact of language use on bilingual's communication behaviors, Du-Babcock $(1999,2006)$ conducted the only empirical research that has directly compared the L1 (Cantonese) and L2 (English) communication of bilingual Hong Kong Chinese. The findings provide explanations for the ways in which Hong Kong bilinguals interacted differently when they used their first language from when they used their second language to make decisions in intracultural small-group meetings. Du-Babcock's (2005) follow-up studies compared the turn-taking behaviors of Asians and Westerners in intracultural and intercultural English meetings. The results showed that participants from Asian cultural societies (a) spoke less and took fewer turns than did those from Western cultures and (b) took more turns 
and spoke for a longer time in intracultural than in intercultural decision-making meetings. In addition, Du-Babcock's intercultural studies concluded that bilinguals exhibited different communication behaviors when communicating with native-English speakers as compared to when using English in a second-language situation.

Du-Babcock's recent collaborative research expanded her previously established theoretical framework on turn-taking and topic management. This study (a) contrasted the communication practices of cultural groups previously categorized as collectivist, high-context communicators, and (b) updated the research on L1 and L2 communication practices of Hong Kong Chinese by adding Japanese communication to the research findings. This recent study has laid the fundamental elements of Japanese and Hong Kong Chinese communication and established a framework for follow-up empirical investigations and theoretical development. The findings suggested that culture and language interactively affect the communication behavior of the two research groups (Du-Babcock \& Tanaka, 2013; DuBabcock, 2013). The findings also revealed that Japanese people consistently used a high-context communication style when they communicated with each other, whether in Japanese (highcontext language) or in English (low-context language), and with the Hong Kong Chinese in English. In contrast, the Hong Kong Chinese unexpectedly deviated from this pattern and used both high-and low-context communication styles. When examining the meeting dialogue, the qualitative data revealed that the Japanese business professionals consistently tried to achieve group harmony by not directly disagreeing with others' opinions, whereas the Hong Kong Chinese exhibited differing patterns for disclosing disagreements in L1 and L2 meetings. In L2 meetings, Hong Kong Chinese business professionals expressed disagreements directly, but in L1 meetings, they expressed disagreements both directly and indirectly.

\section{Communication Studies from Around the World}

Other scholars have also studied communication genres used in English business communication, including business meetings (e.g., Chew 2005; Yeung 2003; Handford 2010), sales information (e.g., Zhu, 2005), electronic forms of communication (e.g., Akar \& LouhialaSalminen, 1999; Habil \& Rafik-Galea, 2005), internal written documents (e.g., Li \& Mead, 2000), application letters (e.g., Al-Ali, 2004), and the conversations that take place in the call center industry (e.g., Forey \& Lockwood, 2007). Cheng and Kong (2009) showcase the work of Asian English business communication within business organizations. Cheng's (2009) study exemplifies the type of work carried out in Hong Kong by identifying what constitutes communicative competence in four key industries underpinning the Hong Kong economy: financial services, tourism, trade and logistics, and professional services.

The Language in the Workplace Project (LWP) by Homes and her associates (Holmes, 2005; Holmes \& Marra, 2004; Holmes \& Stubbe, 2003) examined how people in New Zealand use language in different organizations, including business organizations. "Although the scholars involved with the LWP would consider themselves as business discourse (BD) researchers rather than $\mathrm{BC}$ researchers, their work has nonetheless been influential on business communication (BC) in the region" (Nickerson, 2014, p. 60). Tanaka (2006b) investigated workplace interaction in English in a Japanese chemical company and confirmed Yamada's (1990) research findings. His study further concluded that the Japanese participants were less active when compared to their US and French counterparts. Tanaka's (2006a) study focused on power relationships between the participants, and the results showed that the number of turns taken in a meeting may be affected by the speaker's position or power. A study of Renault-Nissan meetings (Tanaka, 2008), where English was used as a lingua franca, showed differences in participation styles between French and Japanese employees. Tanaka speculated that these differences were attributable to the differing linguistic competence exhibited by French (strong) and Japanese (weak) employees.

\section{International Business (IB) Stream}

The international business stream centers on international business functions and activities as its primary focus but also considers language and culture as important and necessary considerations. It draws on different business disciplines and applies concepts from these disciplines to international business.

\section{Language Sub-stream}

I first deal with language and its interconnection with organizational communication. Corporations (e.g., international, multidomestic, global, and transnational companies) following different management and structural strategies take on different communication networks in communicating with employees around the world (Du-Babcock, 2014, p. 69). For example, in global organizations, the organizational system attempts to develop an integrated communication network, and the personnel across organizational units and at all organizational levels engage in a process of horizontal coordination of enterprise activities. In multi-domestic organizations, there are regional or area divisions. This organizational system largely allows employees to speak their own languages and interact within their own cultures in the horizontal coordination of activities within each area division. In transnational organizations, the organizational 
system resembles that of global organizations but also includes elements of the multi-domestic organization. In these three types of international organizations, proficiency in a linking language is needed to accomplish the internal coordination of enterprise activities and to connect with customers, suppliers, and other external groups. In global and transnational organizations, the tendency is to establish an official company language to enable direct linking language communication channels. In multi-domestic organizations, the tendency is to establish link-pin channels with language link-pins stationed at a language crossover point in the communication channels.

Link-pin communication channels arise when potential communicators do not share competency in any linking languages to confidently exchange messages directly and must choose to pass messages through intermediaries (or link-pins). These linkpin communicators are bilinguals who serve as intermediaries to translate messages across national languages as well as professional genres. Du-Babcock and Babcock (1996) identified and described different link-pin channel patterns. For example, formal link-pin channels entail not only the exchange of messages through an organizational hierarchy in a scalar process but also the horizontal interaction processes among departments in the coordination of work (workflow communication). The language link-pins take on the role of linking their bosses to their immediate subordinates as well as to staff throughout the organization. The following case study illustrates the development of link-pin communication channels to meet with the needs of a firm's internationalization (for details, refer to Du-Babcock \& Babcock, 2009).

This case study describes how professional genres and national language change and develop over time when the company expands into a global market. Early in its history, the production process was basic, and sophisticated technical language was not necessary; therefore, all company communications were in Cantonese as this was the native language of management, workers, and customers. With the introduction of some upscale products and some English-speaking customers, English was introduced into the company's language mix. A tri-national language environment then arose upon moving production facilities to Dongguan, where tri-lingual managers served as national language link-pins and switched among three languages in order to communicate with customers (English, Cantonese, and Mandarin), with the production staff and work force in Dongguan (Mandarin), and with the Cantonese headquarters staff in Hong Kong or among themselves (Cantonese).

\section{Culture Sub-stream}

In this section I describe three culturally influenced manage- ment and communication systems.

\section{Japanese Culturally Influenced Management and Communica- tion System}

The culturally influenced Japanese management and communication systems have historical roots. The distinctive Japanese cultural characteristics of amae (dependence), on (duty), giri (social obligation), and ninjo (human feeling) have influenced Japanese management systems on two levels. At the macro-level, this Japanese management style can be traced to the pre-World War II Zaibatsus and the keiretsu (or economic group or conglomerate) at the end of World War II replacing the Zaibatsus. These two systems formed the framework for development over time of culturally influenced Japanese management and communication systems. At the micro level, these deep Japanese cultural values have also influenced communication at the organizational level. The superior-subordinate relationship resembles a mother-child relationship whereby the subordinates have a desire to be passively loved and protected by their superiors, while the superiors are obliged to take care of the subordinate's wellbeing (Mensik, Grainger, \& Chatterjee, 2006). Being protected, the subordinates, in turn, are expected to be loyal and sacrifice themselves to the company and follow the total command of their top management. Consequently, this Japanese deep cultural characteristic has resulted in a close interdependent relationship between Japanese organizations and their employees.

Communication and decision-making processes in Japanese organizations are based on a culture of collectivism and shared responsibility through consensual decision-making (Mensik, et. al., 2011) or the ringi process (Chen, 1995). In the decision-making process, the Japanese concept of wa or harmony is fundamentally important (Chen, 1995). With the influence of the ringi system, Japanese management is highly participative (Deresky, 1994). Such participation and shared responsibility foster a cohesive work group relationship within quality circles where groups of workers meet regularly to solve problems and improve quality (Deresky, 1994). Many Japanese multinational companies (e.g., Toyota, Mitsubishi Motors Corporation, Toshiba and Komatsu) have improved the technical skills of the employees and reduced defect rates by adopting 'quality circles' (Kumuzawa, 1996).

\section{Korean Culturally Influenced Management and Communication System}

Being adjacent to China, Confucianism has deeply influenced Korea in all aspects. Koreans are family-oriented peoples (Chang \& Chang, 1994) and conceived the universe as a great 
hierarchy, and therefore, Koreans see the father as the central figure in the family (Chung et al., 1997). Similarly, in an organizational context, the concept of paternalism is important within the Korean management system in that the superior or the owner of the company is expected to take the role of father in leading the company, and in return, employees should respect the owner's authority to lead them (Chung et al., 1997).

The Korean culturally influenced management and communication systems have historical roots in conglomerates labeled as Chaebols. Korean Chaebols can be classified in three categories based on the timing of their formation: the late 1950s, the 1960s, and the 1970s (Daidj, 2016). The basis of the management and communication system can be summarized by three driving forces: the self-made founder, management by family, and close government relationships (Paul, Argal, Chaudhary, Pandey, \& Kumar, 2011). The self-made founders provided a unity of direction in their international expansion. Through a deliberate hiring policy, family members were placed in key positions throughout the organization in order to create assured loyalty and ensure that a consistent organizational culture was reinforced and implemented in the way set by the founders. In their relationships with the government, the Chaebols follow government policy in concentrating on targeted industries as designed by the government for international expansion. As such, the government set policy and the chaebols took a subordinate position to execute governmental policy. In return, the government "gave vested property, preferential allotment of foreign grants, and preference in loans" (Paul et al., p. 611). In effect, the government guided and financed the international expansion of the Chaebols. These actions produced a unique combination of free enterprise and state direction.

Research on communication channels in Korean culturally influenced management and communication systems contains inconsistent and possibly contradictory descriptions, and nonresearched areas. The prevailing view is that an authoritarian but paternalistic leadership (Chang \& Chang, 1994) is the common and defining characteristic of Korean management and communication styles. It is reinforced by a clear hierarchical order and a vertical downward communication flow that is acceptable to subordinates in a hierarchy-based Confucian culture (Koo \& Nahm, 1997). The authoritarian style of the Korean manager is rarely despotic (Mensik, Grainger, \& Chatterjee, 2006). Corporate leadership is primarily influenced by its key value of iuhwa or harmony (Chen, 1995).

There also are sketchy and incomplete research studies that contradict, or at least modify this prevailing theoretical view. These accounts (Chen, 1995; Shin, 1998) note that either dual organizational hierarchies with separate scalar processes or func- tional authority relationships outside of the scalar chain of vertical reporting relationships have been established in some Korean MNCs. Family members are hired and assigned to key positions at various organizational levels (Yoo \& Lee, 1987), but the informal communication and communication channels among these family members have not been studied. Paisley (1993) found that Korean MNCs used a version of the Japanese ringi system for major decisions, especially financial ones. For example, in Samsung, the Korean ringi system required 21 "chops" before a final decision was approved by the top executive, and this process took several months (Paisley, 1993). These research and theoretical descriptions of Korean management and communication systems date back to the 1980s and 1990s. In this century, Korean management and communication systems are coming under scrutiny for three major reasons. First, the entrepreneurial founders are nearing retirement age, which raises the issue of continuity as second generation family members assume control of the MNCs and often consider bringing in outside leadership. Second, the centralized and authoritarian management style may not be suited to change or more varied customer tastes and preferences. In theoretical terms, the present conglomerates could be categorized as entrepreneurial machine organizations, and the innovative organization that is decentralized and participative could better suit current market realities in this century. Third, as the MNCs expand in size and operate in differing world areas, they will be exposed to different languages and cultures in external and internal environments. These developments will make it increasingly difficult to maintain unique, Korean culturally influenced management and communication systems in increasingly diverse multi-lingual and multi-cultural settings.

\section{Chinese Culturally and Environmentally Influenced Management} and Communication Systems

While Korea mirrored Japan in globalization, the overseas Chinese (e.g., Singapore, Hong Kong, Taiwan, and other Southeast Asian countries) followed a different path in their movement toward globalization (Westwood, 1992). Rather than developing large conglomerate business structures, the overseas Chinese developed interconnected networks of worldwide family enterprises. These firms pursued low cost-no frills organizational strategies and became the contact points for Western MNCS or more fully concentrated on niche markets. Consistent with the Chinese family being based on kinship relationships, these small overseas Chinese firms developed personalized management systems following the Confucian model. Authority was vested around a central leader (father figure) and family members held key organizational positions. The relationships among these firms were based on trust and there was an absence of formal 
contracts. These practices work well in simple and stable environments, but not in dynamic and complex environments where the tactics lead to the development of insider- outsider relationships (Du-Babcock \& Babcock, 1987) within the organization and to a dependence upon an effective leader who holds a central position in the enterprise.

Hsu (1981) characterized the Chinese culture as being situational and adaptable. These cultural situations dictate appropriate behavior, and Chinese adapt and fit their behavior to situations rather than exhibiting consistent behavioral patterns. With the emergence of changing conditions, Hsu provides a theoretical cultural explanation for the change and evolution of the Chinese family firm. Looking internally, the personalized management system placed a limit on organizational growth. If organizational growth was considered important, then the impetus for reevaluating the management system was presented. With family members being sent abroad to receive a university education (especially MBAs), the conditions for organizational change were activated upon their return. These family members could informally set the stage for change and formally direct change upon succeeding as the family head. In addition, many new entrepreneurial start-ups established participative management styles to avoid the pitfalls of the traditional Chinese family firm. For example, Acer established a hiring policy prohibiting the employment of family members so as to avoid the possible formation of insider-outsider groups (Egri \&Pinfield, 1999). Looking externally, production costs increased in Hong Kong, Taiwan, and Singapore; and, as a result, production facilities were moved to neighboring countries operating with lower costs. Headquarters usually remained in Hong Kong or Taiwan, while the production facilities were moved to Mainland China (Babcock \& Du-Babcock, 2009). With Singapore, the same pattern occurred except that production facilities were moved to Malaysia or other nearby countries. Meanwhile, these countries moved upscale for design, research, and service industries. This movement was aided by educational systems that provided graduates with elevated professional skills; particularly, Singapore actively developed and implemented a government policy to guide this transition.

After Deng's reforms in the early 1980s, Mainland Chinese firms entered international business with China, which has become the contract-manufacturing (or origin equipment manufacturing, OEM) center for Western MNCs. These enterprises are characterized by dual hierarchies of Communist Party members. Private businesses later started and established their own products. Hout and Michael (2014) studied over 30 large private Chinese MNCs in terms of their management and communication practices and found that these firms are often driv- en by an entrepreneurial leader who occupies a dominant role as the head of a traditional overseas Chinese family firm. The organizational configuration and communication system of these private Chinese MNCs resembles an updated version of the traditional overseas Chinese with the exception of its personnel makeup. Rather than being held together by blood family members, the family bond is held by the mutual desire to succeed and the bonding and allegiance to the entrepreneurial leader.

\section{Integration of Research and Theory Building in Business Communication}

The research and theory building streams have looked at Asian business communication from different perspectives and have used different genres from their respective disciplines to describe Asian business communication. Scholars from the culture and language streams have focused on interpersonal communication and have used genres from cultural studies (cultural stream) or language studies (language stream) to guide and report their work. Scholars from the international business stream have focused on organizational communication and have used the management genre but also theory from the culture and language streams to guide and report their findings. There is a movement toward an integration of the research and theory building streams as represented by the development of culture and language sub-streams within the IB stream. This movement has largely centered on developments within each stream (preliminary integration) or between the two streams (partial integration). But there also are some cases of the three streams being integrated (full integration).

To illustrate, this preliminary integration and when referring to the cultural sub-steam of the IB stream, Ouchi (1982) described Theory J (management and communication in Japanese MNCs), Theory A (management and communication in US MNCs), and Theory Z (a proposed combination of Theory J and Theory A), which combines the best elements of both approaches.

For partial integration that refers to the culture and language streams, I use Du-Babcock \& Tanaka’s studies (2013) of Japanese-Hong Kong Chinese interpersonal communication. They identified the interactive influences of language competency and cultural differences on communication patterns in business meetings. To illustrate the full integration of the three streams, I use Du-Babcock's (2017) study of the communication patterns in a Mainland China-based MNC to show a comprehensive example of this integration and the full integration of language, culture and international (expatriate) communication. Set in the early overseas expansion of a Mainland Chinese MNC, this research can be understood against the backdrop of the lan- 
guages used (Chinese, German, and English), the competencies displayed in these languages (language stream), the cultural influences on the communication process (cultural stream), and the business operations and tasks that take place (international business stream). The study described both country organization and headquarters' communication and concentrated on the communication process in a project team. In country organization and headquarters communication, the written communication is coded in Chinese, a character rather than an alphabet based language. This caused German staff to feel excluded and therefore led to worker dissatisfaction. If the communications had been coded in English or German, the Germans could have read the messages and felt more informed in the communication process. At the same time, the Chinese, who were unaware of this dissatisfaction, did not understand as they felt that they were being fully open with the bilingual Germans in their intercultural communication. That is, the Chinese expatriates felt they did not deliberately hide information by coding their reports in Chinese. However, the limited English competences of the Chinese resulted in a less than full information exchange in verbal communication as the Germans could not read the written Chinese reports. In sum, if all three streams are included in the analysis of a business situation, this results in a more complete theoretical explanation of Asian business communication.

\section{Discussion}

\section{Business Communication in Asia}

In this paper I have thus far reviewed and analyzed Asian business communication as Japanese MNCs, followed by the Asian dragons (Korea, Hong Kong, Taiwan, and Singapore) and subsequently Mainland companies entered the global business market. Asian companies initially concentrated on niche markets or became the center of contract manufacturing for Western MNCs but have now progressed to becoming global MNCs with branded products. The management and communication in these Asian MNCs have evolved in this globalization process while still retaining key elements of their respective national cultures, subject to a common historical influence of Confucian doctrines throughout with differing interpretations. Stimulated by the size and importance of this business communication activity, scholars from differing academic disciplines have been attracted to study Asian business communication and have described the evolving business communication process from differing perspectives. Reflecting academic silos, the culture, language, and IB research and theory building streams have largely developed independently (Du-Babcock, 2009 plenary address;
Du-Babcock, 2014). These streams are now in the early stages of moving toward integration with the hopeful possibility of developing an integrated theory of Asian business communication. Along the way, some misconceptions about Asian management and communication have been revised and reflected on. For example, Western theory viewed Japanese MNCs as being highly centralized before empirical research and theory building corrected this misconception. Hence, Ouchi (1982), when examining consensus decision making and communication showed that the Japanese followed a structured approach to communication and decision making that spreads throughout the organization. Here, top management acted primarily as decision confirmers and announcers, rather than as the primary decision makers.

In sum, it is still possible, even with the movement toward globalization, to identify common features of Asian MNCs management and communication systems that distinguish them from Western MNCs. These commonalties stem from a shared historical Confucian influence reflecting the collectivistic rather than individualistic nature of Asian cultures. It also is still possible to differentiate among the management and communication practices of MNCs from different Asian countries that are at different stages of moving toward globalization. Furthermore, the language patterns and communication channels differ between global and transnational MNCs (in terms of the formal adoption of English as a corporate language or policies and practices encouraging English use in direct channels) and multi-domestic MNCs (with English competency necessary for language link-pins in formal and informal link-pin communication channels).

\section{Directions for the Future Research}

With Asia predicted to increasingly become the center of global business in future, the conditions will be set for Asian MNCs to be exposed to people from various cultures and with employees speaking different first languages, with differing external environments in different world areas. Consequently, a multi-directional accommodation process will dictate the nature of communication patterns that evolve in expanding global communication networks within Asian MNCs and with external constituencies. This accommodation process will put the Asian culturally influenced management and communication systems under stress and could stimulate the development of less culturally defined Asian MNCs as diverse groups are integrated within MNCs.

There is a need to develop English competency as well as intercultural communication competency to accommodate global business communication. English is the world's business linking 
language, but competency may also be needed in other languages as well in order to interact with customers and other external groups. These developments hopefully will spur the need for research and theory building and the movement toward the development of a comprehensive theory of Asian business communication as a subset of global business communication theory. The movement toward theory integration and building can be facilitated by (a) building on and extending the integration process that is already in progress and (b) framing research and theory development on existing models and frameworks. I next list some existing models and frameworks that can guide research and theory building in future:

- The language-based communication zones model has been expanded to include intercultural and IB expertise zones and can serve as the framework to study intercultural business communication (Babcock \& Du-Babcock, 2016).

- The link-pin communication model can be used to study link-pins channels.

- Simplified regional and industry BELFs can facilitate research and practice in expanding direct communication in Zones One and Zone Two communication environment.

- The global, transnational, and multi-domestic model can be used as a framework to study the communication patterns in differing types of global MNCs.

- Stage model of growth theory (Greiner, 1972) can be used to study communication patterns that emerge at differing stages of internalization.

- Mintzberg's organizational configurations (1983) can be adapted as an organizing framework for distinguishing communication patterns among machine organizations, professional bureaucracies, entrepreneurial organizations, innovative organizations, and multi-divisional organizations.

\section{Conclusion}

In this paper I reviewed, analyzed, and suggested the future direction of Asian business communication. I would note that there are hopeful signs for expanded research and theory building on Asian business communication. Scholarship and research is shifting to Asia as a way of following the movement of global business communication. Asian scholars educated in the West and have or are becoming change agents upon their return. Asian scholarship is evidenced by the greater participation of Asians in Western journals and, more importantly, the establishment of Asian journals (as evidenced by this issue). To move forward, a comprehensive framework, theories, and models is needed in order to guide future research endeavors in this increasingly diverse and complex globalized business communication envi- ronment and to provide a more complete and comprehensive explanation of international and Asian business communication. Multiple interacting factors are impacting the communication process. A proliferation of research and theory-building efforts from each of the identified streams aims to explain this complexity and diversity, while the silo effect may have deterred and prevented it from being fully integrated so as to adequately explain the global and Asian business communication process. The integrated model and framework are necessary to capture the complexity and diversity of present day and future business communication practice.

The major challenge in the discipline of business communication is the integration that takes on two dimensions. The first dimension is to develop closer connections between research, theory building, and practice and to reduce the time gap or lag in making these connections. The second dimension is to organize theory drawn from the streams of language, culture and international business to gradually move toward developing a more unified and comprehensive theory. Research and theory are at a transitional stage with the possibility of moving either toward a business communication jungle with a proliferation of theories and research findings, or toward an orchard with a movement toward a more unified, comprehensive, and integrated theory.

\section{References}

Akar, D., \& Louhiala-Salminen, L. (1999). Towards a new genre: A comparative study of business faxes. In F. Bargiela-Chiappini, \& C. Nickerson (Eds.), Writing business: genres, media and discourse (pp. 207-226), Harlow, UK: Longman.

Aritz, J., \& Walker, R. (2010). Multicultural groups in decision-making meetings Language proficiency and group performance. Journal of Asian Pacific Communication, 20(2), 307-321.

Babcock, R., \& Du-Babcock, B. (2009). Strategic versus nonstrategic organization development in overseas Chinese family firms: A comparison of traditional and progressive firms. In T. F. Yaeger, \& P. F. Sorensen (Eds.), Strategic organization development: managing change for success (pp. 279-304). Charlotte, NC: Information Age.

Babcock, R., \& Du-Babcock, B. (2016, May). The Evolution of the language-based communication zones model and its current expansion. Paper presented at the 2016 ABC Western Conference, Denver, CO.

Bartlett, C., \& Ghoshal, S. (2002). Managing across boarders: The transnational solution. Brighton, MA: Harvard Business School Press.

Bargiela-Chiappini, F. (2006). (Whose) English(es) for Asian busi- 
ness discourse(s)?. Journal of Asian Pacific Communication, 16(1), 1-23.

Bargiela-Chiappini, F. (2009). Business communication across cultures: A theoretical perspective. In W. Cheng, \& K. C. C. Kong (Eds.), Professional communication collaboration between academics and practitioners (pp. 19-30). Hong Kong: Hong Kong University Press.

Bargiela-Chiappini, F. (2012). Asian business discourse (s). In J. Aritz., \& R. Walker (Eds.), Discourse Perspectives on Organization Communication (pp. 59-79). Madison, WI: Fairleigh Dickinson University Press.

Bilbow, G. T. (1997). Spoken discourse in the multicultural workplace in Hong Kong: Applying a model of discourse as impression management'. In F. Bargiela-Chiappini, \& S. J. Harris (Eds.), The language of business: An international perspective (pp. 21-48). Edinburgh, UK: Edinburgh University Press.

Black, J., Gregersen, H., Mendenhall, M., \& Stroh, L. (1999). Globalizing people through international assignments. Reading, MA: Addison Wesley.

Bond, M. H. (1991). Beyond the Chinese face: Insights from psychology. New York, NY: Oxford University Press.

Breiden, O., Mohr, A. T., \& Mirza, H. R. (2006). An empirical test of a correspondence model of expatriate managers' work adjustment. The International Journal of Human Resource Management, 17(11), 1907-1925.

Brown, P., \& Levison, S. C. (1987). Politeness: Some universals in language usage (Vol. 4). Cambridge, UK: Cambridge University Press.

Caligiuri, P., \& Lazarova, M. (2002). A model for the influence of social interaction and social support for female expatriates' crosscultural adjustment. International Journal of Human Resource Management, 13(5), 761-772.

Cao, D. (2008). Multiplied cultures and market information communication behaviours (Doctoral dissertation). Retrieved from http: //lbms03.cityu.edu.hk/theses/c_ftt/phd-en-b23406999f.pdf

Chang, C. S., \& Chang, N. J. (1994). The Korean management system: Cultural, political, economic foundations. West port, CT: Quorum Books/Greenwood.

Chen, M. (1995). Asian management systems. London, UK: International Thomson Business Press.

Chung, K. H., Lee, H. C., \& Jung, K. H. (1997). Korean management: Global strategy and cultural transformation. Berlin, Germany: Walter de Gruyter.

Craig, R. T. (1999). Communication theory as a field. Communication Theory, 9(2), 119-161.

Daidj, N. (2017). Strategy, structure, and corporate governance: Expressing inter-firm networking group affiliated companies. Abingdon Oxon, UK: Routledge
Deresky, H. (2017). International management: Managing across borders and cultures, text and cases (9th Ed.). Delhi, India: Pearson Education India.

Du-Babcock, B. (1999). Topic management and tum taking in professional communication: First- versus second-language strategies. Management Communication Quarterly, 12(4), 544-574.

Du-Babcock, B. (2000). A model of expatriate on-the-job adaptation to overseas assignments: A communication perspective. Journal of Asia Pacific Business, 2(4), 39-58.

Du-Babcock, B. (2005). An analysis of communication behaviors between intra- and inter-cultural decision-making meetings. Journal of Asian-Pacific Communication, 29, 147-170.

Du-Babcock, B. (2009, November). Is a business communication theory jungle emerging?: Analysis and recommendations. Kitty O. Locker Outstanding Researcher Award Plenary Address at the 74th Annual Convention of the Association for Business Communication, Portsmouth, VA.

Du-Babcock, B. (2012). Development of English for business and professional communication in Asia: A revisit of BELF in the Asian environment. Language Learning Technologies: An International Online Journal, 2(1), 7-30.

Du-Babcock, B. (2013). English as Business Lingua Franca: A comparative analysis of communication behavior and strategies in Asian and European contexts. Iberica, 26, 99-130.

Du-Babcock, B. (2014). Business communication: A revisiting of theory, research, and teaching. In V. Bhatia, \& S. Bremner (Eds.), The Routledge handbook of professional communication (pp. 6884). New York, NY: Routledge.

Du-Babcock, B. (2017). International managerial communication: An analysis of project team communication in a China-based country organization. In B. Griffin (Ed.), Intercultural communication: Strategies, challenges and research (pp. 43-68). New York, NY: Nova Science.

Du-Babcock, B., \& Babcock, R. (1987, May). The effect of multiple language use and differences on the communication process in national and multinational corporations in Taiwan. Paper presented at the 2nd Asian-Pacific Cultural Symposium, Tenri, Japan.

Du-Babcock, B., \& Babcock, R. (1996). Patterns of expatriate-local personnel communication in multinational corporations. The Journal of Business Communication, 33(2), 141-164.

Du-Babcock, B., \& Tanaka, H. (2013). A comparison of the communication behaviors of Hong Kong Chinese and Japanese business professionals in intracultural and intercultural decision-making meetings. Journal of Business and Technical Communication, 27(3), 263-287.

Egri, C. P, \& Pinfield, L. T. (1999). Organizations and the biosphere: Ecologies and environments. In S. Clegg, C. Hardy, \& W. Nord (Eds), Managing organizations: Current Issues (pp. 209-233). Thou- 
sand Oaks, CA: Sage.

Fujio, M., \& Tanaka, H. (2012). Harmonious disagreement in Japanese business discourse. In J. Aritz \& R. Walker (Eds.), Discourse perspectives on organizational communication (pp. 81-100). Madison, WI: Fairleigh Dickinson University Press.

Goffman, E. (1967). Interaction ritual: Essays on face to face behavior. New Brunswick, NJ: Aldline Transaction.

Greiner, L. E. (1972). Evolution and Revolution as Organizations Grow. Harvard Business Review, 50(4), 37-46.

Gudykunst, W. B., \& Nishida, T. (1994). Bridging Japanese/North American differences (Vol. 1). Thousand Oaks, CA: Sage Publications.

Gudykunst, W. B., Matsumoto, Y., Ting-Toomey, S., Nishida, T., Kim, K., \& Heyman, S. (1996). The influence of cultural individualism-collectivism, self construals, and individual values on communication styles across cultures. Human communication research, 22(4), 510-543.

Habil, H., \& Rafik-Galea, S. (2005). Communicating at the workplace: Insights into Malaysian electronic business discourse. Asian Business Discourse(s), 29, 121-143.

Hall, E. T. (1976). Beyond culture. Garden City, NY: Anchor Books. Handford, M. (2010). The language of business meetings. Cambridge, UK: Cambridge University Press.

Herleman, H. A., Britt, T. W., \& Hashima, P. Y. (2008). Ibasho and the adjustment, satisfaction, and well-being of expatriate spouses. International Journal of Intercultural Relations, 32(3), 282-299.

Hofstede, G. (2001). Culture consequences. Thousand Oaks, CA: Sage Publications.

Holmes, J. (2005). Leadership talk: How do leaders 'do mentoring', and is gender relevant?. Journal of Pragmatics, 37(11), 1779-1800.

Holmes, J., \& Stubbe, M. (2015). Power and Politeness in the Workplace: A Sociolinguistic Analysis of Talk at Work. New York, NY: Routledge.

Hong, J. (2005). Conflict management in an age of globalization: A comparison of intracultural and intercultural conflict management strategies between Koreans and Americans. Global Media Journal, 4(6). Retrieved from http://www.globalmediajournal. com/open-access/conflict-management-in-an-age-of-globalizationa-comparison-of-intracultural-and-intercultural-conflict-management-strategies-between-koreans-and-americans.php?aid=35092

Hout, T., \& Michael, D. (2014). A Chinese Approach to Management. Harvard Business Review. Retrieved from: https://hbr.org/2014/ 09/a-chinese-approach-to-management

Hsien-Chin, H. (1944). The Chinese concept of "face". American Anthropologist, 46(1), 45-64.

Hsu, F. L. K. (1981). American and Chinese: passage to differences (3rd Ed.). Honolulu, HA: University of Hawaii Press.

Iwata, Y. (2010). Co-constructing conversations in English and Japa- nese: Are we the same or different in elaborating topics and disclosing ourselves. Paper presented at Sociolinguistics Symposium, Southampton, UK.

Kameda, N. (2013). Future prospects of BELF: Diversion or conversion. Doshisha Business Review, 64(6), 343-357.

Kim, M. S. (2010). Intercultural communication in Asia: Current state and future prospects. Asian Journal of Communication, 20(2), 166-180.

Koo, J. H., \& Nahm, A. C. (Eds.). (1997). An introduction to Korean culture. Carlsbad, CA: Hollym International.

Leung, K. (1988). Some determinants of conflict avoidance. Journal of Cross-Cultural Psychology, 19(1), 125-136.

Ma, Z. (2007). Chinese conflict management styles and negotiation behaviours: An empirical test. International Journal of Cross Cultural Management, 7(1), 101-119.

Majumdar, M. (2015). The ASEAN Way of Conflict Management in the South China Sea. Strategic Analysis, 39(1), 73-87.

Mensik, S., Grainger, R. J., \& Chatterje, S. R. (2011). Trends and transitions in Japanese and Korean management approaches. Retrieved from https://www.researchgate.net/publication/268328209_ Trends_and_Transitions_in_Japanese_and_Korean_Management_ Approaches

Mintzberg, H. (1983). Structure in fives: Designing Effective Organizations. Upper Saddle River, NJ: Prentice-Hall.

Mohammed, U. K., White, G. R., \& Prabhakar, G. P. (2008). Culture and conflict management style of international project managers. International Journal of Business Management, 3(5), 3-11.

Nickerson, C. (2014). Business communication. In V. Bhatia., \& S. Bremner (Eds.), The Routledge handbook of professional communication (pp. 50-67). New York, NY: Routledge.

Oetzel, J. G. (1998). Explaining individual communication processes in homogeneous and heterogeneous groups through individualism-collectivism and self-construal. Human Communication Research, 25(2), 202- 224.

Oetzel, J. G., \& Ting-Toomey, S. (2006). The SAGE handbook of conflict communication: Integrating theory, research, and practice. Thousand Oaks, CA: Sage.

Ohbuchi, K. I., Fukushima, O., \& Tedeschi, J. T. (1999). Cultural values in conflict management: Coal orientation, goal attainment and tactical decision. Journal of Cross-Cultural Psychology, 30(1), 51-71.

Ouchi, W. G. (1982). Theory Z. NewYork, NY: Avon.

Paul, J., Argal, S., Chaudhary, R., Pandey, Y., \& Kumar, M.K.A. (2011). Case Study 6: Management style and practice of South Korean Chaebols. In J. Paul (5th Ed.), International business (pp. 609-612). New Delhi, India: PHI Learning Private Limited.

Peltokorpi, V. (2007). Intercultural communication patterns and tactics: Nordic expatriates in Japan. International Business Re- 
view, 16(1), 68-82.

Peltokorpi, V. (2008). Cross-cultural adjustment of expatriates in Japan. International Journal of Human Resource Management, 19(9), 1588-1606.

Peltokorpi, V. (2010). Intercultural communication in foreign subsidiaries: The influence of expatriates' language and cultural competencies. Scandinavian Journal of Management, 26(2), 176-188.

Peltokorpia,V., \& Clausen, L. (2011). Linguistic and cultural barriers to intercultural communication in foreign subsidiaries. Asian Business \& Management, 10(4), 509-528.

Phuong-Mai, N., Terlouw, C., \& Pilot, A. (2005). Cooperative learning vs Confucian heritage culture's collectivism: Confrontation to reveal some cultural conflicts and mismatch. Asia Europe Journal, 3(3), 403-419.

Rogerson-Revell, P. (1999). Meeting talk: A stylistic approach to teaching meeting skills. In M. Hewings, \& C. Nickerson (Eds.), Business English: Research into Practice (pp. 55-72). Harlow, UK: Longman.

Suchan, J., \& Charles, M. (2006). Business communication research: Past, present, and future. Journal of Business Communication, 43(4), 389-397.

Takeuchi, R., Lepak, D. P., Marinova, S. V., \& Yun, S. (2007). Nonlinear influences of stressors on general adjustment: the case of Japanese expatriates and their spouses. Journal of International Business Studies, 38(6), 928-943.

Tanaka, H. (2006a). Corporate language policy change: The trajectory of management discourse in Japan. Journal of Asian Pacific Communications, 16(1), 25-50.

Tanaka, H. (2006b). Emerging English speaking business discourse in Japan. Journal of Asian Pacific Communication, 16(1), 25-50.

Tanaka, H. (2008). Communications strategies and cultural assumptions: An analysis of French-Japanese business meetings. In S. Tietze (Ed.), International management and language (pp. 154-170). London, UK: Routledge.

Ting-Toomey, S. (2008). Intercultural conflict styles and facework. In W. Donsbach (Ed.), International Encyclopedia of Communication (Vol. 6, pp. 2333-2337). Oxford, UK: Wiley-Blackwell.

Tung, R. (1987). Expatriate assignments: Enhancing success and minimizing failure. Academy of Management Executive, 1(2), 117125.

Westwood, R. I. (1992). Organisational behaviour: Southeast Asian perspectives. Hong Kong: Longman.

Wu. W., Yuen, E., \& Zhu, J. J. (2001). Individualism-collectivism and conflict resolution styles: A cross-cultural study of managers in Singapore. Retrieved from http://www.adr.gov/events/ 2009/nov192009-materials-article. Pdf

Xu, X., \& Du-Babcock, B. (2012). Impact of English-language proficiency on Chinese expatriates' adjustment to overseas assignments. Global Advance in Business Communication, 1(1). Retrieved from http://commons.emich.edu/gabc/vol1/iss1/4

Yamada, H. (1990). Topic management and turn distribution in business meetings: American versus Japanese strategies. Text-Interdisciplinary Journal for the Study of Discourse, 10(3), 271-295.

Yoo, S., \& Lee, S. M. (1987). Management style and practice of Korean Chaebols. California Management Review, 29(4), 95-110.

Zhu, Y. (2005). Written communication across cultures: A sociocognitive perspective on business genres. Philadelphia, PA: John Benjamins. 